\title{
The Old City of Jeddah: from a walled city to a heritage site
}

\author{
M. Bagader \\ Architecture Department, The University of Manchester, UK
}

\begin{abstract}
Jeddah, Jiddah, Jadda or Juddah, also known as the bride of the Red Sea, the port of the two holy cities, the gateway to the city of Makkah and main seaport of contemporary Saudi Arabia, is located on the coast of the Red Sea. Its historic core, known as al-Balad district, is the historic quarter of the city that has been preserved since the city was established in $646 \mathrm{AD}$. The historical values of old Jeddah date back to $250 \mathrm{BC}$, but the interesting thing about the history of the city is that it developed in both the pre-Islamic and the Islamic eras. However, at the beginning of the 16th century the city was attacked by Portuguese troops several times and by some Bedouins, who destroyed most of the city. As a response to these threats the Mamluk Sultan Al-Ghori ordered to build a fortified wall surroundings the city to protect it in 1509 . This wall was the first documented attempt to protect the city since its establishment. Many experts believe that the city wall was the reason for the existence of the historic district "al-Balad" until the present. Nowadays, Jeddah's historic core is acting as a catalyst for different types of built heritage conservation discourses in Saudi Arabia by different stakeholders by trying to inscribe the site as world heritage site at UNESCO. Therefore, how the city wall was the corner stone of preservation the city legacy "heritage"? And why the old city of Jeddah became a historic site candidate to be a world heritage site at UNESCO? In terms of achieving the paper aims, the author will consult the Saudi available literature in the field, official reports and the author will conduct surveys and observations to the old city of Jeddah.

Keywords: Jeddah, Saudi Arabia, heritage, walled cities, preservation, historic quarters.
\end{abstract}




\section{Introduction}

Historic "heritage" walled cities, as well as other historic sites, are facing serious challenges that could threaten its survival for the next generations [1]. These heritage sites require fastidious attention (institutional work) to be protected in order to survive under the current globalization waves and the awareness lack of their importance as national identity and legacy [2]. There are many walled cities in the Arab-Muslim world (globally as well) that considered as the historic urban centres, such as Old Cairo in Egypt, Old Walled City of Shibam in Yemen and others. These historic urban centres are the nuclei of each city because of their historical values. In one way or another, urban centres symbolize and reflect the identity, traditions and norms of each society or community [3].

Back in history, walls were the ideal solution to protect cities from any outside threats. However, there are many cities "historic" worldwide that still existed due to their old walls, which most likely were used for protection. Walled cities, most times, can be preserved and conserved easier than other heritage sites because their walls are defining the city capacity and making an urban boundary [4]. There are several examples in the Arab-Muslim world present the role of the cities' walls in the preservation processes such as Old Fes in Morocco and Old Aleppo in Syria. Both examples were easily preserved as urban fabric not just monuments or selected sites. Jeddah's historic core quarter is one of these historic cities that were preserved even when its old wall was turned down in 1947.

The historic core quarter of Jeddah is today facing serious challenges that could threaten its survival. The high levels of deterioration of buildings, combined with informal transformations carried out by the occupants of the traditional houses and the lack of the conservation management have led to a significant loss of the physical character. In the last 10 years, the Saudi Commission for Tourism and Antiquities (SCTA) and Jeddah Municipality have been trying to have old Jeddah listed as a world heritage site at UNESCO.

This paper attempts to understand the important role of the Old Jeddah's wall in the built-heritage preservation processes since it was built in the $16^{\text {th }}$ century. However, it seems that the built-heritage conservation discourse in Saudi Arabia has shifted from preserving the national identity and legacy towards the commoditisation of heritage for international tourism development by nominating some historic sites to become a world heritage site at UNESCO. Therefore, this paper will attempt to figure out why Jeddah's historic core quarter is nominated to become a world heritage site and how that will benefit from this nomination.

\section{Historic background of the old city of Jeddah}

While the city of Jeddah has continued to develop to the present day, it was initially established when the first "unknown" fishermen came to the area around 350 BC [5]. Some studies argue that the history of the city dates back to the Stone Age due to the old Thamoudian writings found in different sites of the city [6]. Jeddah grew from a small primitive fishing settlement around $350 \mathrm{BC}$ (100 hectares) [7] to a modern metropolis in 2014 (32.500 hectares) [8], stretching 
linearly along the seashore. The small coastal city completely changed with the advent of Islam across the Arabian Peninsula beginning in the $7^{\text {th }}$ century; this had a major effect on the city's urban form and architecture style [9]. Not to mention the importance of the city of Jeddah to the holy city of Mecca as a provider of goods and the main maritime gateway instead of Mecca's old port Shuaybah (roughly 20 kilometres south of Mecca) in $646 \mathrm{AD}$ [6]. Since the city turned out to be the main port of Mecca, Jeddah became an important city in the Hejaz region and in the Islamic world.

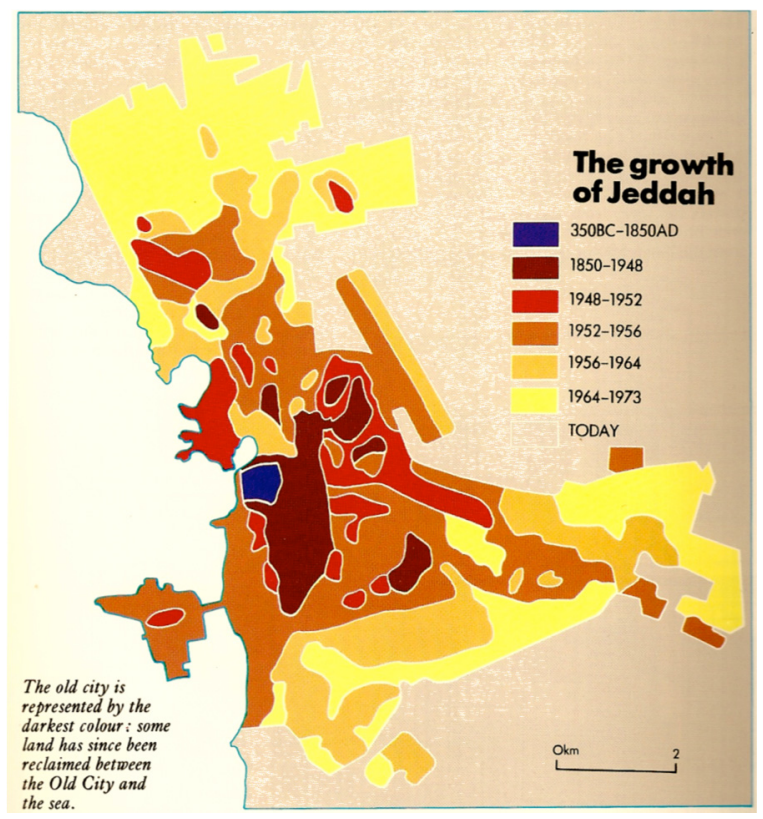

Figure 1: This map shows the physical growth of Jeddah from $350 \mathrm{BC}$ until 1980 occupation (S. International, 1980, 13).

According to the city historians (Alyafi, Badeeb and Alansari) the city had some settlements until the city's wall was built in the $11^{\text {th }}$ century by the Mamluk Sultan Al-Ghori after the Portuguese attacks in 1509 [10]. The city wall defined the urban life within it and shaped the city physically that led the city growth inside its surrounding wall. Since then, the city started to grow with several ethnic backgrounds due to its location near the holy sites. Therefore, the urban and architectural character of old Jeddah symbolizes hundreds of years of development of Islamic architecture covering several architectural styles, such as the Persian, Mamluki, Ottoman and others [8]. This combination of different architectural styles and the mixture socio-economic structure of the city have created an authentic environmental style of building, known as Hejazi architecture or Hejazi city.

The city is distinguished for having a unique urban and architectural heritage that can be witnessed in a number of Red Sea cities, such as Mossawa' and 
Sawaken in the west cost of the Red Sea and in Alwajeh and Yanbu in the west of Red Sea [11, 12]. Jeddah's historic core, as many Islamic cities, reflects the Islamic norms and the social needs, such as privacy, while the urban fabric of the city and the architectural elements of the buildings applied. However, the city urban pattern was developed inside the city wall with clear Islamic principles in regard to the wall and its gates, street width and order, souk system, open public spaces, housing, religious and educational buildings and diplomatic missions [9].

\section{The role of the city wall in the preservation processes}

According to Bagader (2013) there are six phases that lead to the preservation of the old city of Jeddah, being the first and important phase the city wall that drew the city boundary [13]. The city wall was described by many historians and travellers (Ibn Battota, Khasro and others) as the following: the wall was not a regular geometrical shape, but shaped according to the topography of the site with six gates, each one facing a destination and named after it (e.g., Mecca Gate is facing the holy city of Mecca). These gates were closed with wooden flaps constructed by assembling beams that were 12 centimetres thick and 20 centimetres broad, vertically on the outside and horizontally on the inside, and then bonding them with iron strips fastened with huge nails. All six gates were guarded by at least two towers [9].

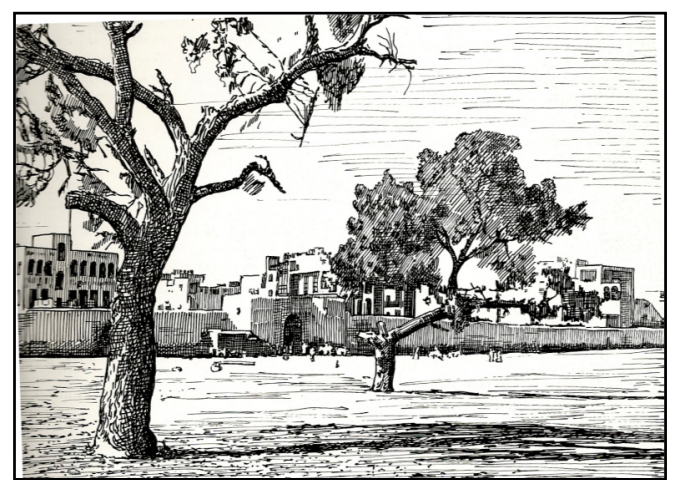

Figure 2: View of the Mecca Gate in the 1940s (Pesce [6]).

The city wall was demolished in 1947 due to the huge growth of the city especially during the first Saudi oil boom in the 1950s, which allowed the city to expand and to develop outside the city wall. However, it seems that the decision makers, at that time, ignored or did not understand the importance of the authenticity of the area especially the old city wall and its gates [14]. The literature about Jeddah presents that the reason behind demolishing the city wall was to use its stones to build the new city pier [6]. It is worth mentioning that some of Jeddah's families moved outside the city wall before turning it down in new settlements totally different of the traditional ones (inside the city wall). By 
planning, or accidentally, there was the buffer zone between the city wall and these new settlements, which defined the historic area even after demolishing the wall. It seems that there was a respect of the old city wall and it was considered as a campus rather than an old area, or it might have been by accident.

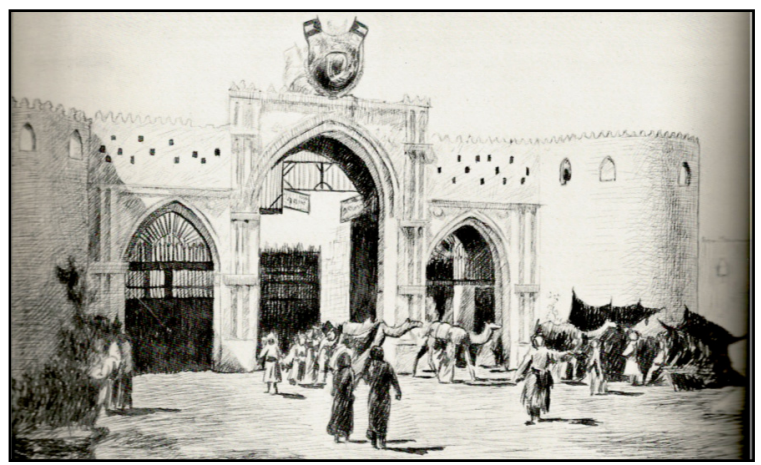

Figure 3: View of the Medina Gate in the 1940s (Pesce [6]).

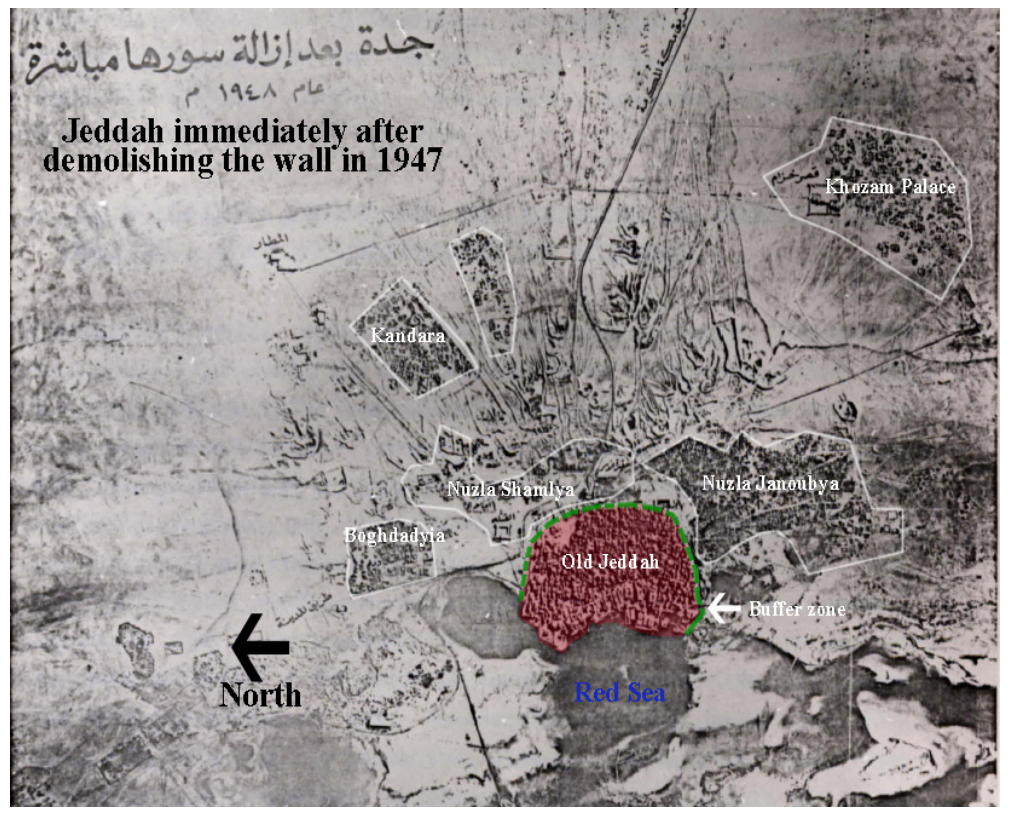

Figure 4: Jeddah Municipality took this map after demolishing the city wall in 1947. This maps presents the existed settlements outside the city wall and the buffer zone. 
In 1970 (i.e., after 23 year the wall demolition), local authorities figured out that the city legacy was in serious threat. As a result, the authorities appointed Sir. Robert Mathew to design a conservation master plan to the historic core of Jeddah [10]. The master plan proposed that the historic area should be designated as national heritage zone, respecting the traditional built environment in the area, as well as, classifying all buildings to three classes regarding their historic and heritage significances. A building code and new regulations were suggested in order to conserve the area [15]. The most important part in this master plan was that the city wall's old footprint had to be visible through designing new gates to cope with the old ones with a view to safeguarding the historic value of the area. Since the conservation master plan was designed and implemented until the present day, its "new" gates may define the historic core of Jeddah, a copy of the old ones.

Finally, the city wall played a significant role in the preservation process even after its demolition. Many experts (Bossa, Adas and Angawi) in preservation of historic centres believe that the old wall has to be considered as the foundation stone for the beginning of a new phase in conserving the city legacy. After demolishing the old city wall, the historic area still existed with its authenticity, integration and sustainability even with oblivious deterioration in the infrastructure and built environment of the area.

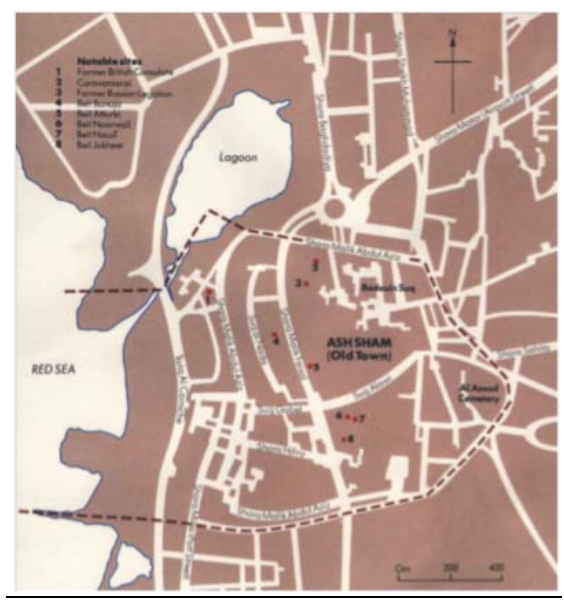

Figure 5: This map shows the designated conservation area (S. International, 1980).

\section{UNESCO inscription and Jeddah's historic core quarter}

Since the first conservation master plan by Mathew in 1970, the old quarter was preserved without any further development in terms of upgrading the area and with many suggestions for that being ignored by local authorities [22]. Actually there were many tough regulations regarding any rehabilitation or upgrading efforts by 
the owners or by investors, which lead to deterioration of the physical conditions in many heritage buildings in the area. Many heritage buildings collapsed and burned because the municipality took care of the whole area without properly applying the first master plan guidance such as, involving the owners and the public, reusing the historic buildings, prompting tourism development, etc. This situation was the same until the SCTA was established in 2001.

SCTA is a governmental agency taking care of antiquities (heritage) and tourism, which are what Jeddah's historic core and all heritage sites in Saudi Arabia need. The SCTA has it owns agenda regarding heritage sites in Saudi Arabia by prompting heritage and use it as economic vitality, which Mathew's master plan suggested in the 1970s [17]. In Jeddah's historic core, the SCTA believes that the area should be under an international supervision to be upgraded. In light of that, the SCTA attempted to inscribe Jeddah's historic core as world heritage site in 2008, but it was rejected because the file was uncompleted [18]. Before elaborating on the reasons given by the UNESCO for its rejection, it might be necessary to indicate that this attempt by SCTA created new understanding of what a file for the built-heritage conservation of the historic Jeddah should contain to be presented for the UNESCO's consideration. Some measures and ideas were put into the file including meticulous details that was thought to be convincing that the historic core of Jeddah matched the UNESCO's standards and criteria, and that the historic area was worth being recognised internationally to deserve recognition and support.

But UNESCO's rejection, perhaps expected by SCTA, presented new standards and requirements that Saudi Arabia has to measure up to qualify for the inscription. According to Ziad Aldrees, the reason for rejecting old Jeddah file was the high level of negligence and the current residents of the area who do not appreciate the historical value of old Jeddah [19]. SCTA and the Jeddah Municipality submitted a new file to the UNESCO in the beginning of 2014 for the inscription of Jeddah's historic core as world heritage site, and the decision is expected to be taken in end of this year (i.e. 2014).

It is important to mention that one of the UNESCO's suggestions to inscribe old Jeddah was establishing a special department (Historic Jeddah Municipality) in 2010, working closely with the SCTA [20]. This new shift entailed new tasks and responsibilities for the new municipality. For instance, they improved the infrastructure of the historic core in an effort to experiment in rehabilitating the historic area in old Jeddah and rented 20 old houses and started rehabilitating them. They maintained the northern part of the old wall of historic Jeddah. They also inaugurated in the historic area a museum for the legacy and heritage of old Jeddah. The museum contained photos and old maps to promulgate awareness among the residents and visitors of the area. They started to build an archive and statistical materials on old Jeddah, and gave the opportunity for investors and house-owners to invest historic buildings [21].

Recently, the Historic Jeddah Municipality started to incorporate private owners to achieve more effective co-operation in order to enhance the inscription file, through "public participation". According to Mona Soilman (2010) “...the Municipality's policy towards private owners was based on strong argumentative 


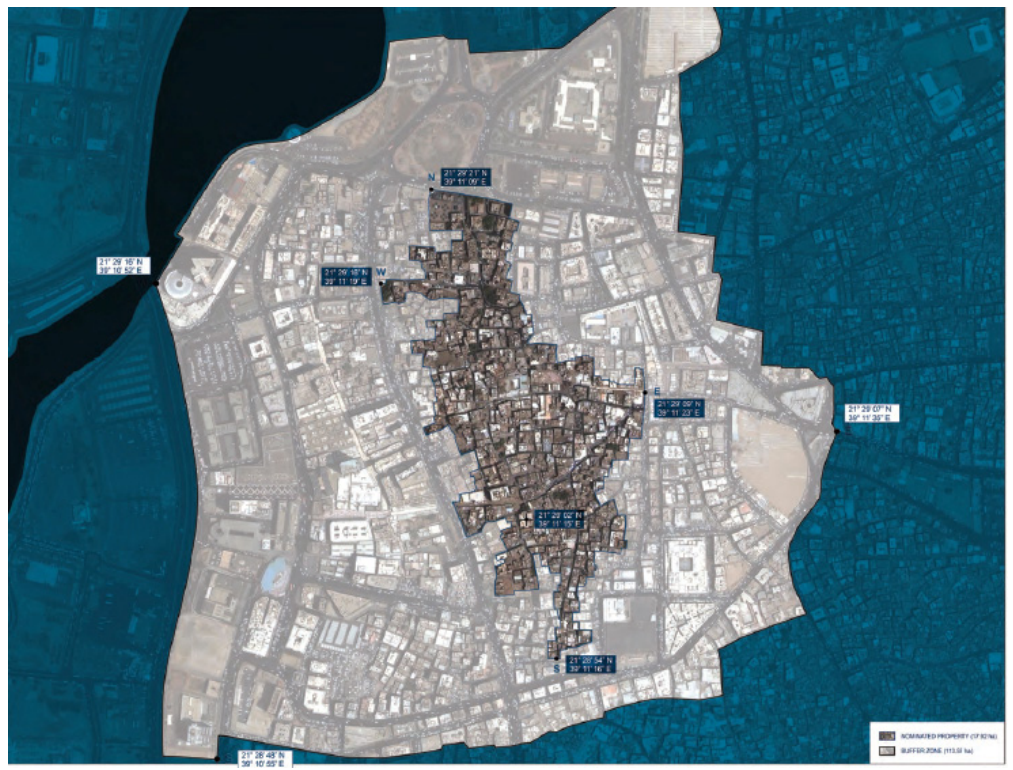

Figure 6: This map shows the nominated area in the historic core of Jeddah to be registered in UNESCO world heritage (SCTA, 2013).

negotiation, rather than on legal weaponry". Thus, the Historic Jeddah Municipality has started to convince the private owners of the value of the conservation scheme; so, the new upgraded municipality introduced a merchant trader approach [3].

Finally, the UNESCO's rejection in 2008 could be a key motivational force to seriously entertain a discourse that will take into consideration all practical factors that will actualize the proper heritage conservation, i.e. planned conservation that takes into consideration sustainable conservation and tourism development in a holistic manner. This shift in the Saudi heritage conservation discourse will pave new understanding of the significance of the historic areas that will not only influence the historic areas but the city as a whole. For sure the inscription will upgrade the historic area because of the international enforcement by the UNESCO and its high standards. The registration will put Jeddah in the international tourism map not for its location near the Islamic holy sites but also for its significant historic quarter.

\section{Conclusion}

City of Jeddah considered as an ancient city with many indications in the history (250 BC), but the golden era of the city started when Muslims inhabited the city and used it as Makkah's main gateway in the $7^{\text {th }}$ century. The city was walled, as many cities in that time for protection, with a comprehensive Islamic urban fabric. Due to the city location near Makkah the city attracted many Muslims from 
different ethnic background to settle down in it, which gave the city its significance in the Hejaz region and the Islamic world. However, after demolishing the city wall (e.g. 1947) the city has suffered from the decay and deterioration but still holding up with some hope. In the 1970s the local authorities with some heritage activists and advocates felt that the city was under the threat of extinction, therefore, an international firm was appointed to design a comprehensive master plan for the city preservation. In a way or another, some of the important suggestions that the master plan proposed were not applied and implemented, which lead to decay many buildings in the area and losing one of the four old quarters in the area "al-Bahar Quarter". This decay was excited until the SCTA (in co-operation with Jeddah Municipality) attempted to inscribe the city at the UNESCO world heritage site list. Finally, the heritage area is still under threat, but in the last five years the observer of the Saudi built-heritage conservation movement can see the dramatic shift in the built-heritage concept. On other words, the Saudi build-heritage conservation discourse changed from a complete neglect during the oil boom years of the 1970s to recent attempts to inscribe different sites on the UNESCO world heritage list to promote tourism in these historic sites. Finally, the historic core of Jeddah area today is on track to be preserved, conserved and rehabilitated in the right way.

\section{References}

[1] Orbasli, A. (2007), Conservation Training in the Middle East, Built Environment 33(3), 307-22

[2] Boussaa, D. (2010), Urban Conservation and Sustainability: Cases from Historic Cities in the Gulf and North Africa, Proceedings of the international conference on technology \& sustainability in the built environment: King Saud University, Riyadh, KSA

[3] Soilman, M. (2010), Sustainable Development between Piecemeal and Urban Based Conservation: Case Study of Jeddah, International Journal of Academic research, vol. 2. No. 5, September, 2010

[4] Steinberg, F. (1994), Conservation and rehabilitation of urban heritage in developing countries, Habitat International Volume 20, Issue 3, September 1996, Pages 463-475

[5] Bokhari, A. Y. (2006), Conservation in the Historic District of Jeddah, Proceedings of the International Conference on redeveloping and rehabilitating traditional areas, King Saud University, Riyadh, KSA

[6] Pesce, A. (1974), Jiddah, Portrait of an Arabian City, Falcon Press, London, UK

[7] Abdulgani, K. (1993), Jeddah: A study of metropolitan change, Cities Magazine, February, pp: 50-59, London, UK

[8] Jeddah Municipality website: https://jeddah.gov.sa/ (accessed on April 2014)

[9] Abu-Ghazzeh, T. (1994), Built Form and Religion: Underlying Structures of Jeddah Al-Qademah, TDSR, vol. 5, No. 11, pp: 49-55, London, UK 
[10] Bokhari, A. Y. (1983), Conservation in the Historic District of Jeddah, in Adaptative Reuse: Integrating Traditional Areas into the Modern Urban Fabric; Cambridge: Margaret Bentley Sevcenko

[11] Miran, J. (2009), Red Sea Citizens: cosmopolitan society and cultural changes in Massawa, Indiana University Press, Bloomington

[12] Orbasli, A and Woodward, S. (2009), Tourism and Heritage Conservation, Handbook of tourism studies, (eds.) Jamal, T. and Robison, M. London: Sage

[13] Bagader, M. (2013), Jeddah's historic core and Evolution of the Saudi Built heritage conservation discourse since the 1970s till 2012, preceding in: In Search for the Kingdom - Emerging scholarship on Saudi Arabia from the First Saudi State to the present conference, Zentrum Moderner Orient 1214 June 2013, - Germany

[14] Adas, A. (2013), the author conducted an interview with Dr. Adas in December 2013 regarding the built-heritage conservation in Saudi in general and Jeddah in particular

[15] Mathew, R. et al. (1980), Study of the Historical District of Jeddah, Jeddah: Ministry of Municipalities and Rural Affairs, Saudi Arabia

[16] Angawi, S. (2013), the author conducted an interview with Dr. Angawi in November 2013 regarding the evolution built-heritage conservation in Saudi in general and Jeddah in particular

[17] SCTA (2010), The SCTA Initiatives Towards Conserving the Saudi Heritage, the SCTA annual report, online report on SCTA.com, Riyadh [in Arabic]

[18] SCTA (2012), Heritage Sites in Saudi Arabia, a special report about the heritage sites that registered and nominated to inscribe in the UNESCO WHC, online report on SCTA.com, Riyadh

[19] Al-Ghazzawi, A. (2012), The Heart of Jeddah, online article: http://mashallahnews.com (accessed on May 2014)

[20] Jeddah Municipality (2011), The Annual Report for Jeddah Historic Muncipility, Jeddah Muncipility press, Jeddah - KSA [in Arabic]

[21] Abu-Daowd and Zazazo (2010), Jeddah: Location Components and Horizons of time, Arab Scientific Publishers Beirut, INC [in Arabic] 